\title{
PENGARUH MODEL PEMBELAJARAN PREDICT-OBSERVE-EXPLAIN TERHADAP HASIL BELAJAR FISIKA SISWA DITINJAU DARI SIKAP ILMIAH
}

\author{
Viddy Mega Samudera, Joni Rokhmat, Wahyudi \\ Program Studi Pendidikan Fisika \\ FKIP, Universitas Mataram \\ Jalan Majapahit No.62, Mataram \\ Email : viddysamudera@gmail.com
}

\begin{abstract}
This study aims to determine: (1) the influence of Predict-Observe-Explain learning model (X1) toward students' physics learning outcomes $(Y)$; (2) the influence of scientific attitude $(X 2)$ toward students physics learning outcomes $(Y)$; (3) the effect of interaction between $(X 1)$ and $(X 2)$ on $(Y)$. This research type is quasi experiment with factorial $2 \times 2$. Its population is all students of class XI IPA in SMA Negeri 6 Mataram years 2016/2017. Samples were taken using cluster random sampling technique and class XI IPA 4 as experimental class and class XI IPA 3 as control class. Data were taken using multiple choice tests with five alternative answers (learning outcomes) and questionnaires (scientific attitudes). The result data was analyzed using two way analysis of variance (anava) with $5 \%$ significant level. The results show that $F_{\text {count }}$ for influence $(X 1)=4.58,(X 2)=25.92$, and interaction between $(X 1)$ and $(X 2)$ is 0.05 with $F_{\text {table }}=3.97$. For the effects of $(X 1)$ and $(X 2)$ there is $F_{\text {count }} \geq F_{\text {table }}$ whereas the interaction effect between $(X 1)$ and $(X 2)$ is obtained $F_{\text {count }}<F_{\text {tabel. }}$ Based on the results of this analysis can be concluded that: (1) there is influence of PredictObserve-Explain learning model toward student's physics learning outcomes; (2) there is influence of scientific attitude toward student's physics learning outcomes; (3) there is no interaction effect between Predict-Observe-Explain learning model with scientific attitude toward student physics learning result.
\end{abstract}

Keywords: Predict-Observe-Explain (POE) learning model, scientific attitude, learning outcomes.

\section{PENDAHULUAN}

Pendidikan merupakan salah satu upaya untuk mencerdaskan kehidupan bangsa dan telah tertera dalam pembukaan UUD 1945 yang berbunyi "Kemudian daripada itu untuk membentuk suatu pemerintah negara Indonesia yang melindungi segenap bangsa Indonesia dan seluruh tumpah darah Indonesia dan untuk memajukan kesejahteraan umum, mencerdaskan kehidupan bangsa dan ikut melaksanakan ketertiban dunia...”. Pada UU Sistem Pendidikan Nasional No. 20 Tahun 2003 dinyatakan bahwa tujuan pendidikan nasional adalah untuk mengembangkan potensi peserta didik agar menjadi manusia beriman dan bertakwa kepada Tuhan Yang Maha Esa, berahlak mulia, sehat, berilmu, cakap, kreatif, mandiri, dan menjadi warganegara yang demokratis, serta bertanggung jawab. Hal ini menjelaskan bahwa pendidikan itu penting untuk semua masyarakat Indonesia.

Pendidikan sains mengambil peran penting dalam mencerdaskan kehidupan bangsa. Istilah sains dapat diartikan sebagai ilmu pengetahuan. Sains lebih khususnya fisika juga turut andil dalam memajukan bangsa Indonesia dan juga menyiapkan sumber daya manusia yang bermutu. Di Indonesia banyak siswa SMA yang mengharumkan nama Indonesia di luar negeri sebagai juara olimpiade, khususnya bidang fisika. Ini membuktikan bahwa kualitas pendidikan di Indonesia tidak kalah saing dengan pendidikan di luar negeri tapi kenyataan di sekolah berbeda dengan apa yang kita dengar selama ini.

Di sekolah, minat belajar siswa rendah, khususnya dalam bidang fisika. Fisika adalah ilmu tentang alam, yang mempelajari tentang unsur-unsur alam semesta ini, mulai dari gaya-gaya yang bekerja, partikel-partikel pembentuk alam hingga sebabakibat yang ditimbulakan. Fisika masih menjadi pelajaran yang menakutkan bagi sebagian siswa karena mereka menganggap fisika penuh dengan rumus yang harus dihafal dan terlalu banyak hitunghitungan yang mereka kerjakan. Ini berdasarkan hasil observasi yang dilakukan di SMA Negeri 6 Mataram.

Hasil yang diperoleh saat observasi di SMA Negeri 6 Mataram adalah siswa yang mempelajari mata pelajaran fisika mengakui bahwa fisika itu terlalu sulit karena banyak rumus dan banyak sekali hitung-hitungan yang membuat mereka menjadi lebih rumit untuk memahaminya. Selain itu, siswa merasa 
lebih cepat bosan belajar fisika karena harus banyak mengerjakan tugas. Siswa juga kurang aktif karena pembelajaran yang digunakan guru lebih banyak bersifat satu arah atau berpusat pada guru.

Berpusatnya pembelajaran kepada guru membuat siswa menjadi lebih banyak mempelajari fisika dengan cara mendengarkan ceramah dan mencatat dipapan. Seharusnya dalam mengajar fisika tidak hanya dengan ceramah ataupun catatan-catatan dipapan tetapi dengan cara yang dapat membuat siswa lebih bisa menguasai konsep fisika.

Jika kita merujuk pada Kurikulum Tingkat Satuan Pendidikan (KTSP) yang menekankan pendekatan kontekstual maka seharusnya siswa terlebih dahulu mempelajari konsep fisika agar dapat mengaitkannya dengan kehidupan sehari-hari lalu mengembangkannya ke dalam bentuk matematis. Pendekatan kontekstual merupakan konsep belajar yang membantu guru mengaitkan antara materi yang diajarkan dengan situasi dunia nyata siswa agar siswa dapat mangaplikasikan ilmunya ke kehidupan meraka sehari-hari dengan tujuh komponen utama pendekatan kontekstual, yaitu: kontruktivisme, bertanya, inkuiri, masyarakat belajar, pemodelan, dan penilaian autentik.

Menggunakan pendekatan kontekstual membuat siswa lebih aktif, giat, dan dapat menguasai pelajaran lebih baik. Untuk menggunakan pendekatan kontekstual juga harus menggunakan model yang tepat karena kesesuaian model dapat mempengaruhi hasil belajar siswa (Nurmayani et al, 2016). Agar pendekatan kontekstual dapat berjalan, salah satunya dapat menerapkan model pembelajaran POE (Predict-Observe-Explain).

Model pembelajaran POE untuk kali pertama dikembangkan oleh White dan Gunstone pada tahun 1992. Model pembelajaran ini digunakan untuk mengungkap kemampuan siswa dalam memprediksi jawaban dari pertanyaan yang diajukan dan mengumpulkan data-data dengan cara observasi untuk menjawab pertanyaan tersebut lalu siswa menjelaskan jawabannya dan mengkorelasikan jawaban mereka dengan hasil prediksi diawal. Kegiatan dari model pembelajaran POE sudah mencakup dari pendekatan kontekstual, seperti kontruktivisme, bertanya, inkuiri, masyarakat belajar, dan penilaian autentik.

Warsono dan Hariyanto (2012) menyatakan bahwa model pembelajaran POE memiliki keunggulan, seperti dapat digunakan untuk mengungkap gagasan awal siswa, membangkitkan diskusi, memberikan informasi kepada guru tentang pemikiran siswa, dan memotivasi siswa agar berkeinginan untuk melakukan eksplorasi konsep serta membangkitkan keinginan untuk menyelidiki. Dengan model pembelajaran ini dapat membuat siswa untuk lebih aktif dan lebih memahami konsep yang dipelajari di dalam kelas (Karamustafaoğlu dan Naaman, 2015). Model pembelajaran ini lebih sering diterapkan pada mata pelajaran kimia. Menurut Anisa et al (2013) terdapat pengaruh model pembelajaran POE terhadap prestasi belajar kognitif siswa pada materi asam, basa, dan garam. Selain model pembelajaran yang mempengaruhi hasil belajar, terdapat juga sikap ilmiah siswa yang mempengaruhinya.

Sikap ilmiah adalah sikap yang ada pada diri siswa seperti sikap ingin tahu tentang benda, fenomena alam, makhluk hidup serta hubungan sebab akibat yang menimbulkan masalah baru yang dapat dipecahkan melalui prosedur yang benar (Harjono et al, 2015). Sikap ilmiah memiliki kontribusi dalam meningkatkan hasil belajar karena dapat membuat siswa jauh lebih aktif, kratif, gigih, dan rajin dalam belajar. Jika siswa memiliki sikap ilmiah dalam belajar maka materi yang diajarkan akan lebih mudah dipahami oleh siswa.

Dari pemaparan di atas, model pembelajaran POE dapat mempengaruhi hasil belajar dan begitupula dengan sikap ilmiah sehingga peneliti bermaksud untuk melakukan penelitian dengan judul "Pengaruh Model Pembelajaran POE (PredictObserve-Explain) Terhadap Hasil Belajar Fisika Siswa Ditinjau dari Sikap Ilmiah" yang bertujaun untuk mengetahui pengaruh model pembelajaran POE terhadap hasil belajar, pengaruh sikap ilmiah terhadap hasil belajar, dan pengaruh interaksi antara keduanya terhadap hasil belajar.

\section{TINJAUAN PUSTAKA}

\section{A. Model Pembelajaran Predict-Observe-Explain (POE)}

Model pembelajaran POE adalah model pembelajaran yang dapat meningkatkan pemahaman dan membangun pengetahuan siswa dengan menggunakan metode ilmiah yaitu siswa memprediksi jawaban lalu mencari data yang sesuai kemudian menjelaskan kaitan data dengan prediksi 
awal siswa. Model pembelajaran POE dilandasi oleh teori kontruktivisme yang beranggapan bahwa melalui kegiatan melakukan prediksi, pengamatan, dan menerangkan sesuatu hasil pengamatan, maka pemahamannya akan meningkat (Warsono dan Hariyanto, 2012).

Langkah-langkah POE memberikan cara penting untuk meningkatkan pemahaman siswa pada ide-ide ilmiah. Pembelajaran dengan model ini menggunakan tiga langkah utama dari metode ilmiah, yaitu membuat prediksi (prediction) atau membuat dugaan terhadap suatu peristiwa fisika lalu, observasi (observation) dengan melakukan penelitian atau pengamatan apa yang terjadi. Pertanyaan pokok dalam observasi adalah apakah prediksinya memang terjadi atau tidak kemudian menjelaskan (explaination) yaitu memberikan penjelasan tentang kesesuaian antara dugaan dan yang sungguh terjadi.

\section{B. Sikap Ilmiah}

Astuti et al (2012) menyatakan bahwa sikap ilmiah dapat mendorong motivasi siswa untuk terus belajar. Sikap ilmiah merupakan sikap yang ada pada diri siswa sebagai seorang ilmuwan dan sekaligus merupakan pendidikan yang bersifat pengembangan kepribadian agar ia terus termotivasi untuk terus belajar. Menurut Harlen dalam Anwar (2009) ada 9 aspek sikap ilmiah, yaitu: sikap ingin tahu, sikap ingin mendapat sesuatu yang baru, sikap kerjasama, sikap tidak putus asa, sikap tidak berprasangka, sikap jujur, sikap bertanggung jawab, sikap berfikir bebas, dan sikap kedisiplinan diri. Dengan adanya sikap ilmiah, siswa akan lebih sering bertanya, berpartisipasi aktif dalam kelompok, dan memiliki antusias mencari jawaban dari buku referensi, sehingga akan meningkatkan kualitas pembelajaran (Puriyandari et al, 2014).

\section{Hasil Belajar}

Hasil belajar adalah pola-pola perbuatan, nilainilai, pengertian-pengertian, sikap-sikap, apresiasi, dan keterampilan (Suprijono, 2012). Hasil belajar didapatkan dari ukuran kuantitatif yang mewakili kemampuan yang dimiliki oleh siswa (Gunada et al, 2015). Hasil belajar yang diamati dibagi pada tiga ranah, yaitu kognitif, afektif, dan psikomotor.

Dari pengertian diatas, dapat diartikan bahwa hasil belajar adalah kemampuan yang dapat diamati dalam diri seseorang dari suatu proses belajar. Hasil belajar terbagi menjadi tiga ranah, yaitu kognitif (pengetahuan), afektif (sikap), dan psikomotor (keterampilan).

\section{METODE}

Penelitian ini dilaksanakan di kelas XI IPA SMAN 6 Mataram tahun pelajaran 2016/2017. Jenis penelitian ini adalah kuasi eksperimen, dengan rancangan faktorial $2 \times 2$ yang dapat dilihat pada Tabel 1.

Tabel 1 Rancangan Faktorial 2 x 2

\begin{tabular}{|c|c|c|c|}
\hline \multicolumn{2}{|r|}{ B } & \multicolumn{2}{|c|}{ Model Pembelajaran (B) } \\
\hline \multicolumn{2}{|l|}{ A } & $\operatorname{POE}\left(\mathrm{B}_{1}\right)$ & $\begin{array}{c}\text { Konvensional } \\
\left(\mathrm{B}_{2}\right)\end{array}$ \\
\hline \multirow{2}{*}{$\begin{array}{l}\text { Sikap } \\
\text { Ilmiah } \\
\text { (A) }\end{array}$} & $\begin{array}{l}\text { Tinggi } \\
\left(A_{1}\right)\end{array}$ & $\mathrm{A}_{1} \mathrm{~B}_{1}$ & $\mathrm{~A}_{1} \mathrm{~B}_{2}$ \\
\hline & $\begin{array}{c}\text { Rendah } \\
\left(\mathrm{A}_{2}\right)\end{array}$ & $\mathrm{A}_{2} \mathrm{~B}_{1}$ & $\mathrm{~A}_{2} \mathrm{~B}_{2}$ \\
\hline
\end{tabular}

$\mathrm{A}_{1}$ merupakan sikap ilmiah tinggi dan $\mathrm{A}_{2}$ merupakan sikap ilmiah rendah sedangkan $B_{1}$ merupakan model pembelajaran POE dan $\mathrm{B}_{2}$ merupakan model pembelajaran konvensional. $A_{1} B_{1}$, $\mathrm{A}_{1} \mathrm{~B}_{2}, \mathrm{~A}_{2} \mathrm{~B}_{1}$, dan $\mathrm{A}_{2} \mathrm{~B}_{2}$ adalah kombinasi dari sikap ilmiah dengan model pembelajaran

Sampel diambil menggunakan teknik cluster random sampling dan diperoleh kelas XI IPA 4 sebagai kelas eksperimen dengan jumlah siswa sebanyak 40 dan kelas XI IPA 3 sebagai kelas kontrol dengan jumlah siswa sebanyak 39 .

Terdapat empat variabel dalam penelitian ini, yaitu variabel bebas, terikat, moderator, dan kontrol. Variabel bebasnya adalah model pembelajaran POE dan model pembelajaran konvensional, variabel terikatnya adalah hasil belajar fisika siswa, variabel moderatornya adalah sikap ilmiah siswa, dan variabel kontrolnya adalah guru yang mengajar, materi ajar, dan waktu pembelajaran.

Instrumen penelitian yang digunakan adalah tes pilihan ganda dengan lima alternatif jawaban untuk hasil belajar fisika siswa dan angket untuk sikap ilmiah. Setelah diuji validitas, realibilitas, tingkat kesukaran, dan daya beda soal diperoleh 30 soal yang digunakan untuk pilihan ganda dan 16 soal angket untuk sikap ilmiah. Uji hipotesis dalam penelitian ini menggunakan analisis varians (anava) dua jalan dengan syarat telah terdistribusi normal dan homogen. 


\section{HASIL PENELITIAN DAN PEMBAHASAN}

\section{A. Hasil Penelitian}

Instrumen yang telah digunakan lalu dihitung untuk mendapatkan hasil penelitian. Hasil penelitian dari sikap ilmiah berupa data sikap ilmiah siswa pada kedua kelompok sampel (Tabel 2) dan data rata-rata nilai hasil belajar kognitif pada kategori sikap ilmiah pada kedua kelas (Tabel 3).

Tabel 2 Data Sikap Ilmiah Siswa pada Kedua Kelompok Sampel

\begin{tabular}{|c|c|c|c|}
\hline Data & & $\begin{array}{c}\text { Kelas } \\
\text { Eksperimen }\end{array}$ & $\begin{array}{l}\text { Kelas } \\
\text { Kontrol }\end{array}$ \\
\hline Jumlah Siswa & & 40 & 39 \\
\hline Skor Tertinggi & & 60 & 60 \\
\hline Skor Terendah & & 40 & 40 \\
\hline $\begin{array}{l}\text { Rata-rata } \\
\text { Ilmiah }\end{array}$ & Sikap & 50,33 & 49,67 \\
\hline $\begin{array}{l}\text { Jumlah } \\
\text { kategori Tinggi }\end{array}$ & Siswa & 21 & 19 \\
\hline $\begin{array}{l}\text { Jumlah } \\
\text { kategori Rendah }\end{array}$ & Siswa & 19 & 20 \\
\hline
\end{tabular}

Untuk mendapatkan jumlah siswa pada kategori sikap ilmiah tinggi dan rendah adalah dengan cara siswa yang memiliki nilai sikap ilmiah minimal sama dengan nilai rata-ratanya dikategorikan tinggi dan sisanya dikategorikan rendah. Pada kelas eksperimen dengan rata-rata nilai sikap ilmiah 50,33 diperoleh jumlah siswa dengan sikap ilmiah kategori tinggi sebanyak 21 dan kategori rendah sebanyak 19 sedangkan pada kelas kontrol dengan rata-rata nilai sikap ilmiah 49,67 diperoleh jumlah siswa dengan sikap ilmiah kategori tinggi sebanyak 19 dan kategori rendah sebanyak 20.

Tabel 3 Rata-rata Nilai Hasil Belajar Kognitif pada Kategori Sikap Ilmiah

\begin{tabular}{ccc}
\hline & \multicolumn{2}{c}{ Model Pembelajaran (B) } \\
\cline { 2 - 3 } Sikap Ilmiah (A) & POE $\left(\mathrm{B}_{1}\right)$ & $\begin{array}{c}\text { Konvensional } \\
\left(\mathrm{B}_{2}\right)\end{array}$ \\
\hline Tinggi $\left(\mathrm{A}_{1}\right)$ & 78 & 73 \\
Rendah $\left(\mathrm{A}_{2}\right)$ & 66 & 62 \\
\hline
\end{tabular}

Nilai siswa yang berada pada sikap ilmiah tinggi memiliki rata-rata lebih tinggi dari pada siswa yang memiliki sikap ilmiah rendah dan rata-rata nilai pada kelas yang diterapkan model pembelajaran POE lebih tinggi dari pada kelas yang diterapkan model pembelajaran konvensional.

Untuk mencari hasil belajar fisika siswa dipergunakan tes pilihan ganda 30 soal. Soal-soal yang diberikan adalah soal yang telah lulus uji instrumen. Sebelum diberikan perlakuan kepada kedua kelas tersebut, terlebih dahulu dilakukan tes awal untuk mengetahui kemampuan awal peserta didik serta untuk mengatahui keseragaman siswa yang ada pada kedua kelas tersebut. Pada akhir pertemuan, dilakukanlah tes akhir untuk mengetahui hasil belajar siswa. Adapun hasil tes awal dan akhir peserta didik pada kelas eksperimen dan kelas kontrol dapat dilihat pada Tabel 4.

Tabel 4 Hasil Tes Awal dan Tes Akhir pada Kedua Kelompok Sampel

\begin{tabular}{lcccc}
\hline \multirow{2}{*}{ Data } & \multicolumn{2}{c}{ Tes Awal } & \multicolumn{2}{c}{ Tes Akhir } \\
\cline { 2 - 5 } & $\begin{array}{c}\text { Kelas } \\
\text { Eksperimen }\end{array}$ & $\begin{array}{c}\text { Kelas } \\
\text { Kontrol }\end{array}$ & $\begin{array}{c}\text { Kelas } \\
\text { Eksperimen }\end{array}$ & $\begin{array}{c}\text { Kelas } \\
\text { Kontrol }\end{array}$ \\
\hline Jumlah & 40 & 39 & 40 & 39 \\
Siswa & & & & \\
Nilai & 77 & 77 & 97 & 90 \\
$\begin{array}{l}\text { Tertinggi } \\
\text { Nilai }\end{array}$ & 37 & 37 & 50 & 43 \\
$\begin{array}{l}\text { Terendah } \\
\text { Rata-rata }\end{array}$ & 56,33 & 55,98 & 72,25 & 67.01 \\
\hline
\end{tabular}

Terdapat perbedaan rata-rata hasil tes awal siswa pada kedua kelompok sampel. Sebelum diberi perlakuan, nilai rata-rata tes awal kelas eksperimen adalah 56,33 sedangkan untuk kelas kontrol adalah 55,98. Hasil tes awal pada kedua kelompok sampel disajikan pada Gambar 1.

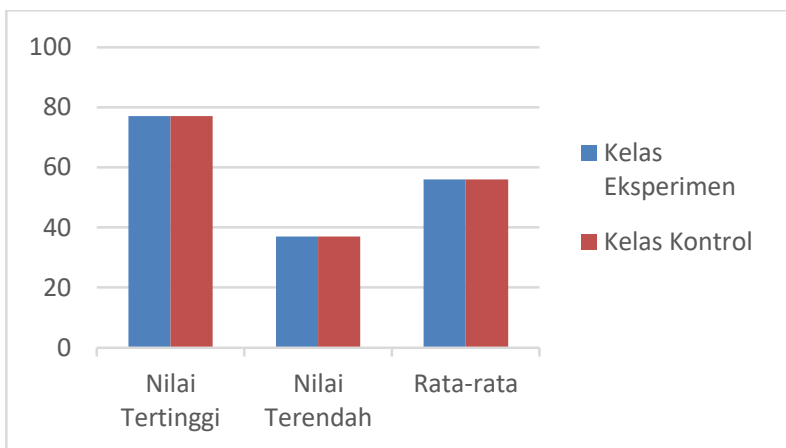

Gambar 1 Hasil Tes Awal pada Kedua Kelompok Sampel

Setelah diberi perlakuan berupa pembelajaran model POE untuk kelas eksperimen dan model 
pembelajaran konvensional untuk kelas kontrol, nilai rata-rata tes akhir kedua kelompok meningkat, yaitu 72,25 untuk kelas eksperimen dan 67.01 untuk kelas kontrol. Hasil tes akhir kedua kelompok disajikan pada Gambar 2.

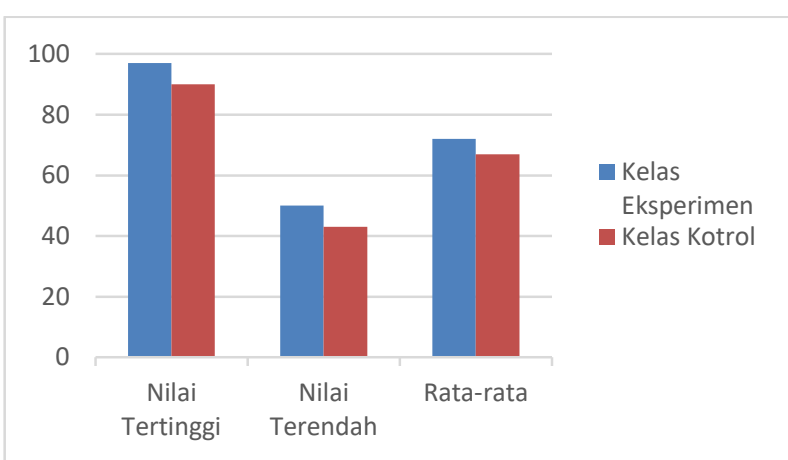

Gambar 2 Hasil Tes Akhir pada Kedua Kelompok Sampel

Selain hasil belajar pada ranah kognitif, diperlihatkan juga hasil belajar ranah afektif dan psikomotor sebagai data penunjang hasil belajar siswa selama proses pembelajaran berlangsung pada kedua kelas yang terdapat pada Tabel 5 .

Tabel 5 Rata-rata Hasil Belajar Ranah Afektif dan Psikomotor pada Kedua Kelompok Sampel

\begin{tabular}{ccc}
\hline Ranah & Eksperimen & Kontrol \\
\hline Afektif & 87,19 & 85,63 \\
Psikomotor & 95,09 & 94,09 \\
\hline
\end{tabular}

Untuk menentukan uji statistik yang digunakan maka perlu mengetahui homogenitas dan normalitas data.

Uji homogenitas digunakan untuk dapat mengetahui kedua kelas memiliki kemampuan yang sama. Pengujiannya menggunakan uji $\mathrm{F}$ pada taraf signifikan $5 \%$. Hasilnya tes awal memiliki $F_{\text {hitung }}$ sebesar 1,200 dan tes akhir sebesar 1,070 dengan $F_{\text {tabel }}$ sebesar 1,709 sehingga $F_{\text {hitung }}<F_{\text {tabel. }}$ Jadi, disimpulkan kedua kelas tersebut adalah homogen.

Uji normalitas digunakan untuk mengetahui normal tidaknya suatu data. Pengujiannya menggunakan uji Chi Kuadrat. Hasilnya tes awal untuk kelas eksperimen sebesar 1,69 dan kelas kontrol sebesar 3,61. Hasil tes akhir untuk kelas eksperimen sebesar 1,94 dan kelas kontrol sebesar

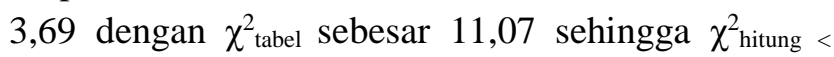

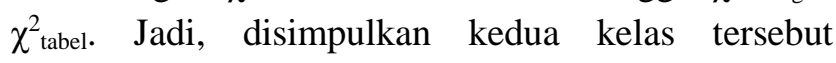
terdistribusi normal.
Diketahui data adalah homogen dan terdistribusi normal sehingga uji statistik yang digunakan adalah anava dua jalan. Uji anava dua jalan digunakan untuk mengetahui pengaruh model pembelajaran, sikap ilmiah, dan interaksi antara keduanya terhadap hasil belajar fisika siswa. Hasil analisis uji hipotesis menggunakan anava dua jalan dapat dilihat pada Tabel 6 .

Tabel 6 Hasil Uji Hipotesis Anava Dua Jalan

\begin{tabular}{lrrl}
\hline \multicolumn{1}{c}{ Sumber } & Fhitung & Ftabel & P \\
\hline Model (B) & 4,58 & 3,96 & 0,05 \\
Sikap Ilmiah (A) & 25,92 & 3,96 & 0,05 \\
Interaksi (AB) & 0,05 & 3,96 & 0,05 \\
\hline
\end{tabular}

Berdasarkan Tabel 6, didapatkan hasil sebagai berikut.

1. Hipotesis 1

Diperoleh $\mathrm{F}_{\text {hitung }}=4,58$ sedangkan $\mathrm{F}_{\text {tabel }}=3,97$. Hal ini menunjukkan bahwa $F_{\text {hitung }} \geq \mathrm{F}_{\text {tabel, }}$, dengan demikian $\mathrm{H}_{01}$ ditolak dan $\mathrm{H}_{\mathrm{a} 1}$ diterima, artinya ada pengaruh model pembelajaran POE terhadap hasil belajar fisika siswa.

2. Hipotesis 2

Diperoleh $\mathrm{F}_{\text {hitung }}=25,92$ sedangkan $\mathrm{F}_{\text {tabel }}=$ 3,97. Hal ini menunjukkan bahwa $F_{\text {hitung }} \geq F_{\text {tabel, }}$ dengan demikian $\mathrm{H}_{02}$ ditolak dan $\mathrm{H}_{\mathrm{a} 2}$ diterima, artinya ada pengaruh sikap ilmiah terhadap hasil belajar fisika siswa.

\section{Hipotesis 3}

Diperoleh $\mathrm{F}_{\text {hitung }}=0,05$ sedangkan $\mathrm{F}_{\text {tabel }}=3,98$. Hal ini menunjukkan bahwa $\mathrm{F}_{\text {hitung }}<\mathrm{F}_{\text {tabel, dengan }}$ demikian $\mathrm{H}_{03}$ diterima dan $\mathrm{H}_{\mathrm{a}}$ ditolak, artinya tidak ada pengaruh interaksi antara model pembelajaran POE dengan sikap ilmiah terhadap hasil belajar fisika siswa.

\section{B. Pembahasan}

Data yang diperoleh dalam penelitian ini adalah hasil belajar fisika siswa pada materi fluida statis. Hasil penelitian yang didapat masuk ke dalam pembahasan berikut.

\section{Pengaruh Model Pembelajaran Terhadap Hasil Belajar Fisika Siswa}

Berdasarkan Tabel 4, terlihat ada peningkatan rata-rata nilai tes akhir dari tes awal yang telah dilakukan. Peningkatan rata-rata nilai ini terjadi pada kedua kelas sampel. Pada kelas eksperimen yang diberikan perlakuan model pembelajaran POE 
memiliki rata-rata nilai tes awal sebesar 56,33 dan meningkat menjadi 72,25 saat tes akhir. Pada kelas kontrol yang diberikan perlakuan pembelajaran konvensional memiliki rata-rata nilai tes awal sebesar 55,98 dan meningkat menjadi 67,01 saat tes akhir. Walaupun keduanya memiliki rata-rata nilai yang meningkat tetapi pada kelas yang diterapkan model pembelajaran POE jauh lebih baik dari pada kelas yang diterapkan model pembelajaran konvensional terbukti dengan perbedaan rata-rata nilai tes akhir pada kedua kelas.

Selain itu, berdasarkan analisis statistik dengan anava dua jalan diperoleh $F_{\text {hitung }}$ untuk hipotesis pertama lebih besar dari pada $\mathrm{F}_{\text {tabel }}$ yang nilainya dapat dilihat pada Tabel 6. Hasil ini membuktikan bahwa sehingga $\mathrm{H}_{01}$ ditolak, artinya ada pengaruh model pembelajaran POE terhadap hasil belajar fisika siswa.

Bedasarkan uji statistik tersebut, telah diketahui bahwa model pembelajaran POE lebih baik dari pada model pembelajaran konvensional. Hal ini menunjukkan bahwa pada kelas yang menggunakan model pembelajaran POE akan menghasilkan hasil belajar fisika yang lebih baik dari pada kelas yang menerapkan model pembelajaran konvensional. Hal ini dikarenakan model pembelajaran POE memberikan kesempatan kepada siswa untuk aktif dalam mencari data (observasi) terhadap materi yang sedang dipelajari. Hasil ini sejalan dengan penelitian yang dilakukan oleh Puriyandari et al (2014) yang menyatakan bahwa prestasi belajar kognitif siswa yang dikenai model pembelajaran POE lebih tinggi dari siswa yang dikenai metode ceramah dan tanya jawab.

Model pembelajaran POE dilandasi oleh teori kontruktivisme yang beranggapan bahwa dengan tiga langkah pembelajaran model POE maka dapat meningkatkan hasil belajar fisika siswa. POE adalah model yang mempercayakan siswa untuk mengerjakan sebuah permasalah dalam pembelajaran. Dengan menerapkan model ini dapat meningkatkan aktifitas karena siswa akan melakukan observasi untuk membuktikan prediksi yang mereka nyatakan adalah tepat, ini sekaligus dapat memberikan pengetahuan, konsep, dan pemahaman yang lebih kepada siswa dalam mempelajari materi fisika. Arends (2012) menyatakan bahwa pengetahuan, konsep, dan pemahaman adalah hal penting dalam pembelajaran sekolah jaman sekarang dan guru tidak hanya memberikan tugas kepada siswa.

Dalam melakukan observasi guru dapat memfasilitasi, membimbing, dan mengarahkan siswa. Guru dapat memberikan kegiatan eksperimen atau kegiatan-kegiatan lain yang berhubungan dengan materi yang diajarkan. Setelah siswa melakukan observasi, siswa dapat menjelaskan hasil observasinya kepada guru dan teman-temannya untuk membuktikan prediksi yang dinyatakan itu benar atau salah. Dengan menerapkan model pembelajaran POE, siswa akan menjadi lebih aktif dalam kelas dan dapat meningkatkan hasil belajar melalui kegiatan-kegiatan yang dilakukan.

Hasil belajar yang diamati dengan model pembelajaran POE tidak hanya pada ranah kognitif tapi juga pada ranah afektif dan psikomotor. Pada Tabel 5, untuk rata-rata nilai afektif dan psikomotor pada kelas eksperimen lebih baik dari pada kelas kontrol. Untuk nilai afektif dinilai perindividu di dalam kelas. Perbedaan rata-rata nilai afektif ini dikarenakan beberapa anak pada kelas kontrol memiliki sikap yang kurang baik. Untuk psikomotor dinilai saat siswa melakukan eksperimen atau kegiatan yang melakukan keterampilan. Jadi, siswa dinilai secara perkelompok dan dinilai berdasarkan keterampilan mereka dalam melakukan eksperimen.

Keterampilan siswa dalam melakukan eksperimen masih kurang karena siswa tidak terbiasa dengan kegiatan tersebut sehingga terkadang guru ikut membantu siswa yang masih memiliki masalah. Kurangnya pengalaman siswa dalam melakukan eksperimen dapat diatasi dengan menerapkan model yang dapat membuat siswa terbiasa dengan kegiatan yang mengasah keterampilan salah satunya dengan menerapkan model pembelajaran POE.

\section{Pengaruh Sikap Ilmiah Terhadap Hasil Belajar Fisika Siswa}

Bedasarkan Tabel 6, dari hasil analisis statistik anava dua jalan didapatkan $F_{\text {hitung }}$ lebih besar dari $\mathrm{F}_{\text {tabel }}$ sehingga $\mathrm{H}_{02}$ ditolak yang artinya ada pengaruh sikap ilmiah terhadap hasil belajar fisika siswa. Sikap ilmiah dapat mempengaruhi hasil belajar, terbukti pada Tabel 3 terlihat siswa yang memiliki sikap ilmiah tinggi memiliki rata-rata nilai yang lebih baik dari pada siswa yang memiliki sikap ilmiah rendah. Pada kelas eksperimen, siswa dengan sikap ilmiah tinggi memiliki rata-rata nilai hasil belajar sebesar 78 sedangkan siswa yang memiliki sikap ilmiah rendah 
memiliki rata-rata nilai sebesar 66. Pada kelas kontrol, siswa dengan sikap ilmiah tinggi memiliki rata-rata nilai hasil belajar sebesar 73 sedangkan siswa yang memiliki sikap ilmiah rendah memilki rata-rata nilai sebesar 62. Hal ini membuktikan bahwa sikap ilmiah berpengaruh terhadap hasil belajar fisika siswa. Walaupun kedua kelas mendapat perlakuan yang berbeda pada penerapan model pembelajaran tetapi siswa dengan sikap ilmiah tinggi mendapatkan hasil belajar yang lebih baik dari pada siswa yang memiliki sikap ilmiah rendah. Penelitian ini sejalan dengan Anisa et al (2013) yang menyatakan sikap ilmiah berpengaruh terhadap hasil belajar kognitif siswa.

Sikap ilmiah merupakan sikap yang ada pada diri siswa sebagai seorang ilmuwan dan sekaligus merupakan pendidikan yang bersifat pengembangan kepribadian agar siswa terus termotivasi untuk belajar. Siswa yang memiliki sikap ilmiah tinggi cenderung berprestasi lebih baik dari pada siswa yang mempunyai sikap ilmiah rendah. Hal ini dikarenakan siswa yang memiliki sikap ilmiah tinggi memiliki rasa ingin tahu, respek terhadap data dan fakta, berpikir kritis, kreatif, berpikiran terbuka, dapat bekerjasama, tekun, dan peka terhadap lingkungan sekitar.

Umumnya yang mempengaruhi sikap ilmiah adalah ketertarikan siswa terhadap pelajaran fisika, kemampuan personal, dan suasana pembelajaran. Dengan suasana yang kondusif dan berbeda, siswa dapat meningkatkan sikap ilmiah serta minat pada pelajaran fisika. Pada penelitian ini, siswa sangat antusias dalam melakukan praktikum karena mereka dapat aktif dan kratif dalam memahami pembelajaran fisika. Hal inilah yang membuat sikap ilmiah berpengaruh terhadap hasil belajar fisika. Dari pemaparan yang dijelaskan dapat disimpulkan bahwa hasil belajar fisika siswa dengan sikap ilmiah tinggi lebih baik dari pada siswa dengan sikap ilmiah rendah sehingga sikap ilmiah berpengaruh terhadap hasil belajar siswa.

\section{Interaksi Model Pembelajaran POE dengan Sikap Ilmiah Terhadap Hasil Belajar Fisika Siswa}

Bedasarkan Tabel 6, dari hasil analisis statistik anava dua jalan didapatkan $F_{\text {hitung }}$ lebih kecil dari $\mathrm{F}_{\text {tabel }}$ sehingga $\mathrm{H}_{03}$ diterima yang artinya tidak ada pengaruh interaksi antara model pembelajaran POE dengan sikap ilmiah terhadap hasil belajar fisika siswa. Model pembelajaran POE secara signifikan berpengaruh terhadap hasil belajar fisika siswa begitupula dengan sikap ilmiah pada materi fluida statis, tetapi diantara keduanya tidak ada interaksi dalam mempengaruhi hasil belajar.

Menurut Anisa et al (2013) menyatakan bahwa tidak adanya interaksi antara model pembelajaran dengan sikap ilmiah karena yang paling berperan terhadap hasil belajar adalah model yang digunakan, baik itu sikap ilmiah tinggi ataupun rendah jika dikenakan model pembelajaran POE maka hasil belajarnya meningkat sehingga interaksi diantara keduanya tidak berpengaruh terhadap hasil belajar.

Tidak ada interaksi juga dapat dijelaskan bahwa sikap ilmiah merupakan variabel moderator yang dapat mempengaruhi (memperkuat/ memperlemah) hubungan antara model pembelajaran (variabel bebas) dengan hasil belajar (variabel terikat). Model pembelajaran POE sudah mempengaruhi hasil belajar fisika dan dengan ditambahkan variabel moderator yaitu sikap ilmiah ternyata memperlemah hubungan anatara keduanya terbukti dengan tidak adanya pengaruh interaksi model pembelajaran POE dengan sikap ilmiah terhadap hasil belajar fisika siswa.

\section{PENUTUP}

Berdasarkan data yang diperoleh dan hasil dari analisis data yang telah dikemukakan dapat disimpulkan beberapa hal, yaitu:

1. Terdapat pengaruh model pembelajaran POE terhadap hasil belajar fisika siswa. Model pembelajaran POE memberikan pengaruh yang lebih baik dari pada model pembelajaran konvensional tehadap hasil belajar fisika siswa.

2. Terdapat pengaruh sikap ilmiah terhadap hasil belajar fisika siswa. Hasil belajar fisika siswa yang mempunyai sika ilmiah tinggi akan memberikan pengaruh yang lebih baik dari pada siswa yang mempunyai sikap ilmiah rendah.

3. Tidak terdapat pengaruh interaksi antara model pembelajaran POE dengan sikap ilmiah terhadap hasil belajar fisika siswa.

Beberapa saran yang ingin diajukan peneliti untuk penelitian mengenai model pembelajaran POE dan sikap ilmiah, yaitu: (1) Pada penggunaan model pemebelajaran POE, guru dapat berinovasi dengan menggunakan berbagai macam metode. Tidak harus 
selalu kegiatan eksperimen tapi juga dapat melakukan studytour ke tempat yang mendukung materi pembelajaran yang diajarkan. (2) Dalam pembelajaran di kelas, guru perlu meningkatkan sikap ilmiah siswa dalam pembelajaran sehingga siswa terbiasa untuk berpikir kritis dan sistematis.

\section{REFERENSI}

Anisa, D. N., Masykuri, M., dan Yamtinah, S. (2013). Pengaruh Model Pembelajaran POE (Predict, Observe, and Explanation) dan Sikap Ilmiah Terhadap Prestasi Belajar Siswa pada Materi Asam, Basa dan Garam Kelas VII Semester 1 SMP N 1 Jaten Tahun Pelajaran 2012/2013. Jurnal Pendidikan Kimia, 2(2), 16-23.

Anwar, H. (2009). Penilaiain Sikap Ilmiah Dalam Pembelajaran Sains. Jurnal Pelangi Ilmu. 2(5), 103-114.

Arends, R. I. (2012). Learning to Teach, Ninth Edition. New York: McGraw-Hill Companies.

Astuti, R., Sunarno, W., dan Sudarisman, S. (2012). Pembelajaran IPA dengan Pendekatan Keterampilan Proses Sains Menggunakan Metode Eksperimen Bebas Termodifikasi dan Ekperimen Terbimbing Ditinjau dari Sikap Ilmiah dan Motivasi Belajar Siswa. Jurnal Inkuiri. 1(1), 51-59.

Gunada, I. W., Sahidu, H., dan Sutrio, S. (2015). Pengembangan Perangkat Pembelajaran Fisika Berbasis Masalah untuk Meningkatkan Hasil Belajar dan Sikap Ilmiah Mahasiswa. Jurnal Pendidikan dan Teknologi, 1(1), 38-46.

Harjono, A., Jufri, A. W., dan Arizona, K. (2016). Implementasi Media Tiga Dimensi Kemagnetan Berbasis Inkuiri Melalui Strategi Kooperatif Terhadap Sikap Ilmiah Siswa. Jurnal Pendidikan Fisika dan Teknologi, 1(1), 15-23.

Karamustafaoğlu, S., dan Naaman, R. M. (2015). Understanding Electrochemistry Concepts using the Predict-Observe-Explain Strategy. Eurasia Journal of Mathematics, Science \& Technology Education, 11(5), 923-936.

Nurmayani, N., Syuaib, M. Z., dan Ardhuha, J. (2016). Pengaruh Gaya Belajar VAK pada Penerapan Model Pembelajaran Problem Based Learning Terhadap Hasil Belajar IPA Fisika Siswa SMP Negeri 2 Narmada Tahun
Ajaran 2015/2016. Jurnal Pendidikan Fisika dan Teknologi, 2(1), 13-21.

Puriyandari, D., Saputro, A. N. C., dan Masykuri, M. (2014). Penerapan Model Pembelajaran Prediction, Observation and Explaination (POE) Dilengkapi Lembar Kerja Siswa (LKS) Untuk Menigkatkan Sikap Ilmiah dan Prestasi Belajar Materi Kelarutan dan Hasil Kali Kelarutan Siswa Kelas XI IPA Semester Genap SMA Negeri 1 Ngemplak Tahun Pelajaran 2012/2013. Jurnal Pendidikan Kimia (JPK). 3(1), 24-30.

Suprijono, A. (2012). Cooperative Learning: Teori dan Aplikasi PAIKEM. Yogyakarta: Pustaka Belajar.

Warsono dan Hariyanto. (2012). Pembelajaran Aktif. Bandung: PT. Remaja Rosdakarya. 